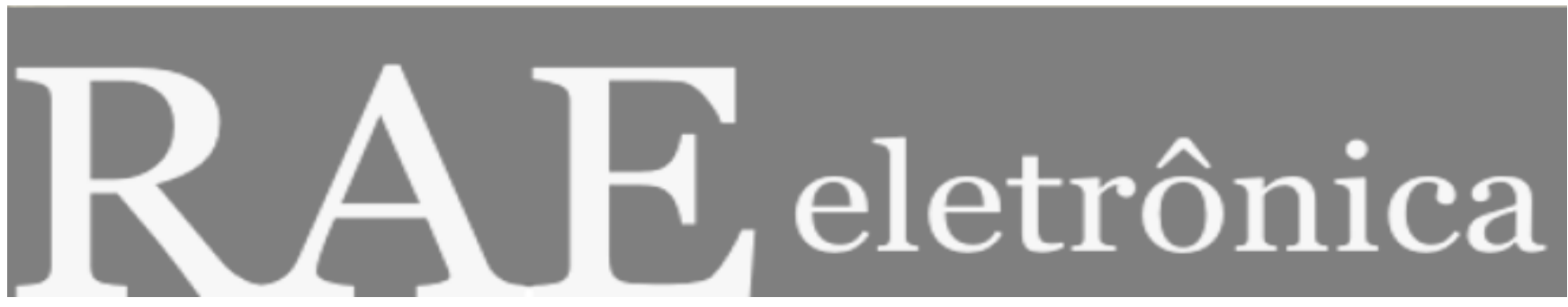

ANALYSIS OF THE ALUMINUM PRODUCTION CHAIN IN BRAZIL

Por

Claude Machline

Fernando Garcia

José Bento Amaral Jr.

Wilson Nobre

RAE-eletrônica, Volume 1, Número 1, jan-jun/2002.

http://www.rae.com.br/eletronica/index.cfm?FuseAction=Artigo\&ID=1285\&Secao=OPERA/LOGI\&Volume=1\&Numero= $1 \& A n o=2002$

CCopyright, 2002, RAE-eletrônica. Todos os direitos, inclusive de tradução, são reservados. É permitido citar parte de artigos sem autorização prévia desde que seja identificada a fonte. A reprodução total de artigos é proibida. Os artigos só devem ser usados para uso pessoal e não-comercial. Em caso de dúvidas, consulte a redação: redacao@rae.com.br.

A RAE-eletrônica é a revista on-line da FGV-EAESP, totalmente aberta e criada com o objetivo de agilizar a veiculação de trabalhos inéditos. Lançada em janeiro de 2002, com perfil acadêmico, é dedicada a professores, pesquisadores e estudantes. Para mais informações consulte o site www.rae.com.br/eletronica.

RAE-eletrônica

ISSN 1676-5648

(C)2002 Editora: Fundação Getulio Vargas - Escola de Administração de Empresas de São Paulo.
F U N D A Ç Ã 0 GETULIO VARGAS

Escola de Administração de Empresas de São Paulo 


\title{
ANALYSIS OF THE ALUMINUM PRODUCTION CHAIN IN BRAZIL
}

\section{Claude Machline}

Professor Emeritus, FGV-EAESP.

E-mail: cmachline@fgvsp.br

\section{Fernando Garcia}

Professor, Department of Economy, FGV-EAESP.

E-mail:fgarcia@,fgvsp.br

José Bento Amaral Jr.

Professor, Operations Management Department, FGV-EAESP.

E-mail:jamaral@fgvsp.br

\section{Wilson Nobre}

Professor, Operations Management Department, FGV-EAESP.

E-mail: wnobre@fgvsp.br

\section{RESUMO}

O objetivo deste trabalho é analisar a cadeia produtiva do alumínio no Brasil.Definiu-se cadeia produtiva como o conjunto estruturado de operações necessárias para transformar matérias-primas em uma família de produtos acabados. O estudo de uma cadeia desse tipo destina-se a aumentar a competitividade dos seus elementos constitutivos, focando seus problemas e criando soluções para a melhoria dos resultados empresariais. O artigo é fruto de uma pesquisa realizada em 2000 a pedido da Associação Brasileira de Alumínio - ABAL. A metodologia utilizada consistiu em definir as etapas básicas do processo produtivo; visitar usinas e fábricas; entrevistar executivos e técnicos; e analisar o considerável acervo de dados macro e micro-econômicos obtidos. Alguns princípios de dinâmica de cadeia produtiva são enunciados. A indústria de alumínio nacional apresenta hoje problemas agudos, resultantes da desvalorização da moeda, do custo e da escassez de energia elétrica, de impostos em cascata e da falta de economia de escala, configurando um espectro de ameaças à sua sobrevivência.

\begin{abstract}
This paper's objective is to analyze the Brazilian aluminum production chain. We define production chain as the structured set of operations necessary to transform raw materials into a related group of finished products. The study of such a chain aims at increasing the competitiveness of its elements, focusing on their problems and devising solutions. The methodology adopted consisted in defining the basic production steps; visit plants and factories; interview executives; and analyze the wealth of data gathered. Some principles of production chain dynamics are proposed. The aluminum industry offers today, in Brazil, acute problems, due to currency devaluation, cost and scarcity of electrical energy, invoicing taxes and lack of economies of scale, which threaten its survival.
\end{abstract}

PALAVRAS-CHAVE

Cadeia produtiva do alumínio, alumínio no Brasil, competitividade, agregação de valor.

\section{KEY WORDS}

Aluminum production chain, aluminum in Brazil, competitiveness, value added. 


\section{INTRODUCTION. OBJECTIVES OF THE PAPER}

There is a lot of talk today about production chains. But not much seems to have been written on this subject. When the ABAL, the Brazilian Aluminum Association, which congregates most of the industries which compose the production chain of this important metal, asked in 2000 the Getulio Vargas Foundation to undertake a research on the problems affecting its associates, the Foundation considered it an unique opportunity to study a chain in its entirety, since this very active Association represents the whole chain, personifies the chain itself. The purpose of this paper is to summarize some findings of the project, stressing the problems which affect its competitiveness and establishing some principles of production chains functioning.

\section{PRODUCTION CHAIN AND PRODUCTIVE SECTORS}

An industry, like the aluminum industry, is composed of all the companies whose main activities are focused on this metal and its transformations. An industry is divided in tiers, or sectors, like for instance the smelting sector, which comprises the corporations which operate smelters in this country, namely Alcan, Alcoa, Billiton, Cia. Brasileira de Alumínio, Vale do Rio Doce. The aluminum production chain considers the sequence of operations necessary to manufacture finished products made of this metal, starting from raw materials. Bauxite extraction; its transformation in alumina; electrolytic smelting of alumina to obtain aluminum; transformation of the metal into semi-finished products, on their turn manufactured into finished products; and eventually the recovery of scrap, such are the sectors of the aluminum industry. One can see below a schematic representation of the production chain, cutting through the sectors of the aluminum industry.

Sectors

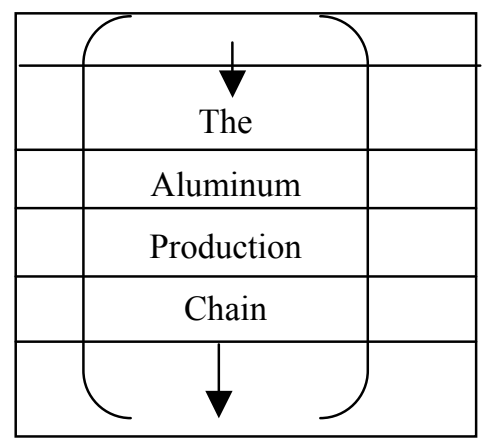

Raw materials

Alumina

Primary aluminum

Semi-finished products

Finished products

Scrap recovery

\section{A METHODOLOGY FOR PRODUCTION CHAIN STUDY}

The methodology used for the aluminum production chain study consisted of the following steps:

1. Establish the starting and end stages of the chain

2. Describe the several phases of the production macro-processes

3. Find out the standard inputs per ton of product 
4. Compute the physical volumes of raw materials, intermediate products, semi-finished and end products used and produced per year

5. Determine the unit prices and standard consumption factors of all inputs

6. Discover the value added at each step

7. Establish the main problems

8. Devise solutions

\section{THE ALUMINUM PRODUCTION CHAIN}

The overall production chain of aluminum is represented in Figure 1.

The chain is traditionally constituted by six steps:

- $\quad$ Bauxite mining

- $\quad$ Alumina production

- $\quad$ Aluminum electrolytic smelting

- $\quad$ Manufacturing of intermediary, semi-finished products

- $\quad$ Fabrication of end products

- $\quad$ Aluminum scrap recovery

See Figure 1

\section{VALUE ADDED ALONG THE PRODUCTION CHAIN}

The first steps of the aluminum production chain involve commodities, whose prices are easily established. The metal itself is negotiated at the London Metal Exchange. Figure 2 shows that the nominal price for the $99,7 \%$ pure ingot, 3 months settlement, was US\$1,386 per ton in 1999, and US\$ 1,545 in 2000. There is a "premium" usually paid in Brazil - but also in most countries -, above the LME price. The premium varies between US\$ 80 and US\$ 200 per ton, according to the circumstances. It is considered to be a compensation for transportation expenses.

See Figure 2

The deflated price, taking the 1990 dollar for base, was US\$ 1,090 per ton, but a substantial increase is foreseen for years 2001 and 2002.

As all commodities, one sees that aluminum price fluctuates considerably. 
As one progresses along the chain, it becomes increasingly more difficult to establish the price of the products. Commodities are transformed in specialties. Prices depend on private negotiations between producer and customer and fluctuate according to the law of supply and demand.

There is often an established "conversion price" to transform an intermediate product into a more advanced one. Some prices seen in Figure 1 result from the addition of this conversion price to the initial price of the material to be converted.

If we accept the prices indicated in Figure 1, the value added along some tracks are seen below.

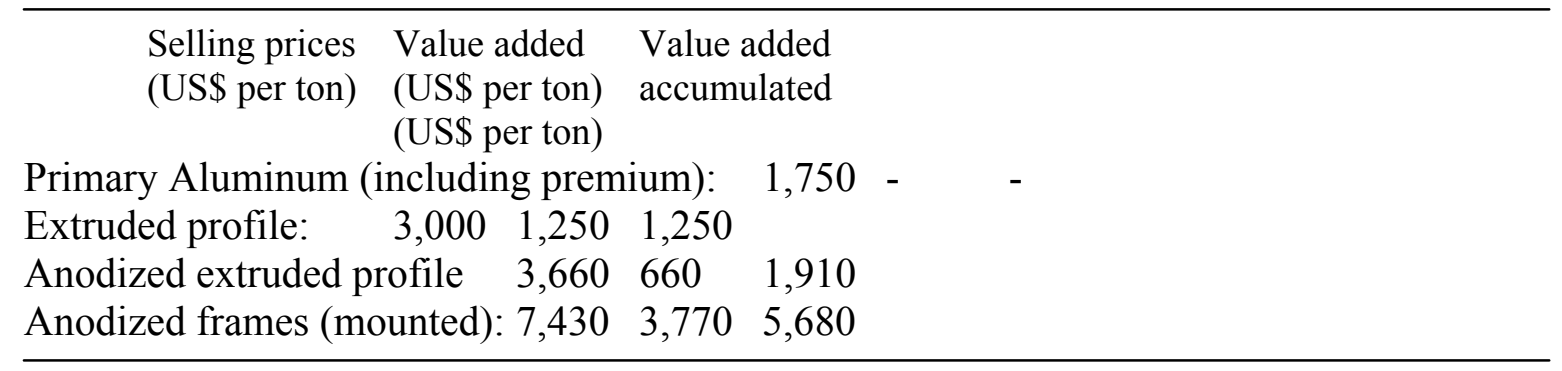

All these values are free of taxes.

This is as exceptional value added, the reason being that the frames, used in bathroom boxes and construction in general, are hand mounted in buildings.

Usually, value added in aluminum conversion is small, compared to other production chains, like, for instance, the steel and copper chains.

The cable track is more representative of the rather low added value in the aluminum chain.

\begin{tabular}{llll}
\hline $\begin{array}{r}\text { Selling prices } \\
\text { (US\$ per ton) }\end{array}$ & $\begin{array}{l}\text { Value added } \\
\text { (US\$ per ton) } \\
\text { (US\$ per ton) }\end{array}$ & $\begin{array}{l}\text { Accumulated } \\
\text { Value added }\end{array}$ \\
Primary aluminum (including premium) & $1,750 \quad-$
\end{tabular}

Much deeper studies should be realized so as to calculate the profit added value at each conversion along the production chain. This requires a detailed knowledge of the transformation and overhead costs, not an easy matter to compute.

Value added is related to technology. It requires considerable technical knowledge to forge or cast aluminum automobile parts. They reach a price of US\$ 8,000 a ton. But the necessary know how is difficult to acquire.

In some production chains the value added at the final stages is considerable. A good grade of iron ore is worth US\$ 20 a ton, FOB, at Brazil export harbours. Common steel is worth US\$ 300 a ton. The iron and steel contents of a popular automobile can be valued at US\$ 5,000 a ton. The steel parts of a war tank are priced at US\$50,000 a ton.

Good quality quartz flakes are exported by Brazil at US\$ 1,00 per kilo. Transformed in crystals, it is worth US\$ 100 per kilo. Chips and optical fibers made of extremely purified quartz might be worth US\$ 1,000 per kilo. On the other side, technical advances reduce constantly the price of products of high technological content. 
Value added analysis is relevant for a company in order to decide whether to integrate vertically or, on the contrary, to divest itself of downstream or upstream activities.

In order to reduce its dependency of outside sources, one Brazilian company integrated strategically its aluminum operations, from bauxite mining to rolled sheet, and generates half of the electric power it requires. Generating energy might become part of the aluminum business.

\section{THE PRODUCTION CHAIN DYNAMICS}

A production chain bears many characteristics of the production-distribution models studied in industrial dynamics years ago.

Like in all systems, there are weaker links, mostly the smaller finished products manufacturers and stronger ones, mostly the huge primary plants. The system is not better than its weakest link. The more elements exist along the line, the smallest is the system reliability; the more elements in parallel, the larger is the system reliability.

There are also differences between a production chain and an industrial dynamic system. A chain is not planned; it has not a clearly defined objective, its elements do not work for a common purpose, as do supply chains or ECR chains. No feedback control is established for a chain performance. The interests of the players might conflict, especially over the prices charged by suppliers to purchasers.

Production chains display a much larger range of processes and transformations than a production-distribution system. Instead of a single factory, a warehouse, distributors and retailers, it encompasses a host of successive industrial and logistic operations.

It is legitimate to infer that external shock will cause even larger oscillations in dependent variables of a chain than in the classical industry dynamic model. Therefore, the tendency to loose its stability is larger.

In January 1999, Brazil had to devaluate its currency, the Real, from the rate of 1 Real to an US dollar, to the rate of 1,8 Real to an US dollar. After this devaluation, the Real was left to fluctuate freely in the exchange market.

As aluminum is quoted in dollars at the LME value, and was worth about US\$1,500 at the time, the primary metal exporter would receive $\mathrm{R} \$ 2,700$ per ton against the former $\mathrm{R} \$ 1,500$ a ton. He would prefer to export the metal than to sell it at $\mathrm{R} \$ 1,500$ a ton in the domestic market. The new metal price and lack of offer in the country originated a conflict in the chain. Eventually, the parts agreed that the price change would be slowly transferred to the remote ends of the chain, over the next months, so as to reduce the impact of the currency devaluation, which was at last felt by the final consumer. Aluminum artifacts, already expensive, became luxury goods.

After the currency shock, Brazil is waiting now for an electric power shock.

\section{THE TAXATION CHAIN}

As Figures 3 and 4 show, the Brazilian production and export of primary aluminum stopped to increase from 1990 on. This observation comes as a surprise for the executives interviewed, since Brazil seems to be in condition to produce much more than the present 1,200,000 tons per year. The 
country has the third largest bauxite reserve in the world and the largest hydroelectric potential. Actually the combination of lack of capital, lack of purchasing power, lack of economy of scale and excess of taxation are strangling the Brazilian aluminum production chain.

See Figure 3

See Figure 4

Excepting the first links of the chain, bauxite and alumina, which do not seem to have trouble, the main problems mentioned by the primary aluminum producers and the manufacturers are the following:

1. High and increasing taxation on aluminum and the end products partially made of this metal, like soft drinks, beer, cosmetics, motor vehicles and buildings. This factor was cited by all people interviewed.

2. High price and scarcity, or threat of scarcity, of electric power. Average price of MWh higher than in Canada, Australia, Venezuela and other countries.

3. Excessive protection of imported products, like aluminum plates.

4. Lack of standardization of end products, resulting in exceedingly small production lots.

5. Lack of effective lobbying at the federal and state government levels to protect the aluminum industry. Also lack of institutional marketing to promote the aluminum advantages compared to rival and cheaper materials, like plastics, glass, paper and cardboard, and also steel.

Many problems were mentioned. Since taxation was the common denominator of complaints, the authors computed the tax contents of aluminum products at several levels of the production chain, obtaining the following results.

Gross tax content, Brazil, 1998

$$
\%
$$

- Metal level

Primary aluminum

- Semi-finished products

Profile

Anodized Profile

Plate

- Finished Products

Frame

Household goods

Can
30.7

31.1

29.4

39.5

\section{9}

The tax chain is impairing the competitiveness of aluminum. The rival materials are favored by smaller tax content.

A specific cumulative group of taxes and contributions, nicknamed "cascade tax", has as exponential effect on the price of the final product. It amounts to $4,198 \%$ on gross invoicing, at each 
invoicing stage. After three invoicing stages along the production chain, the effect is to increase the price by $(1.04198)^{3}$, or $13.13 \%$. A vertically integrated company would be hurt by this tax only once.

\section{CONCLUSIONS}

In this study of the Brazilian aluminum industry competitiveness, undertaken in 2000, a production chain is defined as the sequence of operations performed in order to manufacture finished products, starting from raw materials and moving through all the sectors of this industry.

The methodology used in the research consisted of analyzing information gathered in plant visits, in executives interviews and in the survey of technical and economical data. The many problems found in the chain were classified and deeply examined. Value added at each stage of the production chain was computed.

A production chain is a very complex set of systems linked one to another. In face of external shocks, like currency devaluation, price fluctuations, new products competition, electric power scarcity, and tax increases, this super-system reacts like the production-distribution systems described in Industrial Dynamics.

The Brazilian aluminum industry, already stagnant for a decade, is seriously affected by these disturbances.

Aside from the elimination of cumulative taxation, which increases exponentially products, a solution for the industry is to become self sufficient in electric power, investing in electrical generation, and incorporating this activity in their production chain.

\section{ACKNOWLEDGMENTS}

The authors thank ABAL, the Associação Brasileira de Alumínio, its directors, secretaries and committees, who supplied them with a considerable part of the information which made this study feasible. They acknowledge also the contribution given by the many executives and technicians of the companies they visited. Their opinions and comments constituted valid subsidies to this study. The authors are grateful to many other professors and consultants of the Getulio Vargas Foundation who collaborated in the research.

\section{Artigo recebido em 25.09.2001. Aprovado em 07.11.2001}

\section{BIBLIOGRAPHY}

Comparativo de Custos na Indústria de Alumínio Primário Brasileira, Ministério da Economia, Fazenda e Planejamento, Secretaria Nacional de Economia, Departamento da Indústria e do Comércio, Divisão do Complexo de Metalurgia, Julho 1990, Brasília.

Usina de Tucuruí, Efeito do Aumento dos Custos de Construção nos Preços de Energia Elétrica Fornecida aos Mercados Consumidores, ABAL-Associação Brasileira de Alumínio, São Paulo, Maio 1993. 
Usina de Itaipú, Influência sobre o Fornecimento de Energia das Regiões Sul/Sudeste do Brasil, ABAL-Associação Brasileira de Alumínio, São Paulo, Maio 1993.

BRITTO, Jorge Nogueira de Paiva, Estudo da Competitividade da Indústria Brasileira, Competitividade da Indústria de Alumínio, IE-Unicamp-IEI-UFRJ-FDC-FUNCEX, Campinas, 1993.

Aluminium Rolling Industry Service, 1996-1997, Demand, Supply and Cost Analysis, CRU International Ltd., London, 1996.

Metais não Ferrosos, Estudo da Competitividade do Setor, Relatório Alumínio, ANDERSEN WORLDWIDE, São Paulo, Janeiro 1997.

Estudo da Competitividade do Setor de Cabos Condutores de Alumínio, ABAL-Associação Brasileira de Alumínio, São Paulo, Agosto 1997.

AMARANTE DE ANDRADE, Maria Lúcia, et al., Evolução do Mercado de Alumínio 2 BNDES, Área de Operações Industriais 2, AO2, Gerência Setorial de Mineração e Metalurgia, Rio de Janeiro, Abril 1998.

A Reciclagem do Alumínio no Brasil, Programa Brasileiro de Reciclagem, Ministério da Indústria, do Comércio e do Turismo, ABAL-Associação Brasileira de Alumínio, São Paulo, Outubro 1998.

Reunião com o Ministro de Desenvolvimento, Indústria e Comércio, Celso Lafer, IBS-Instituto Brasileiro de Siderurgia, Rio de Janeiro, 19 de janeiro 1999.

Termo de Referência da Indústria de Alumínio, Programa Especial de Exportação, Setor de Metais Não Ferrosos-Alumínio, ABAL-Associação Brasileira de Alumínio, São Paulo, maio 1999.

ANUÁRIOS ESTATÍSTICOS ABAL, de 1993 a 1999, ABAL-Associação Brasileira de Alumínio, São Paulo.

IPI-Incidência sobre Produtos de Alumínio, Protocolo enviado ao Dr. Silvio Medeiros Costa, Secretário da Receita Federal, em 27 de setembro de 1994, pela ABAL, sob o número SECR-316-94. 


\section{Figure 1: Flowchart of Aluminum Productive Chain}

Prices in 1998 , in US\$/metric ton or US\$/MWh, free of taxes.

Inputs necessary to produce 1 ton.

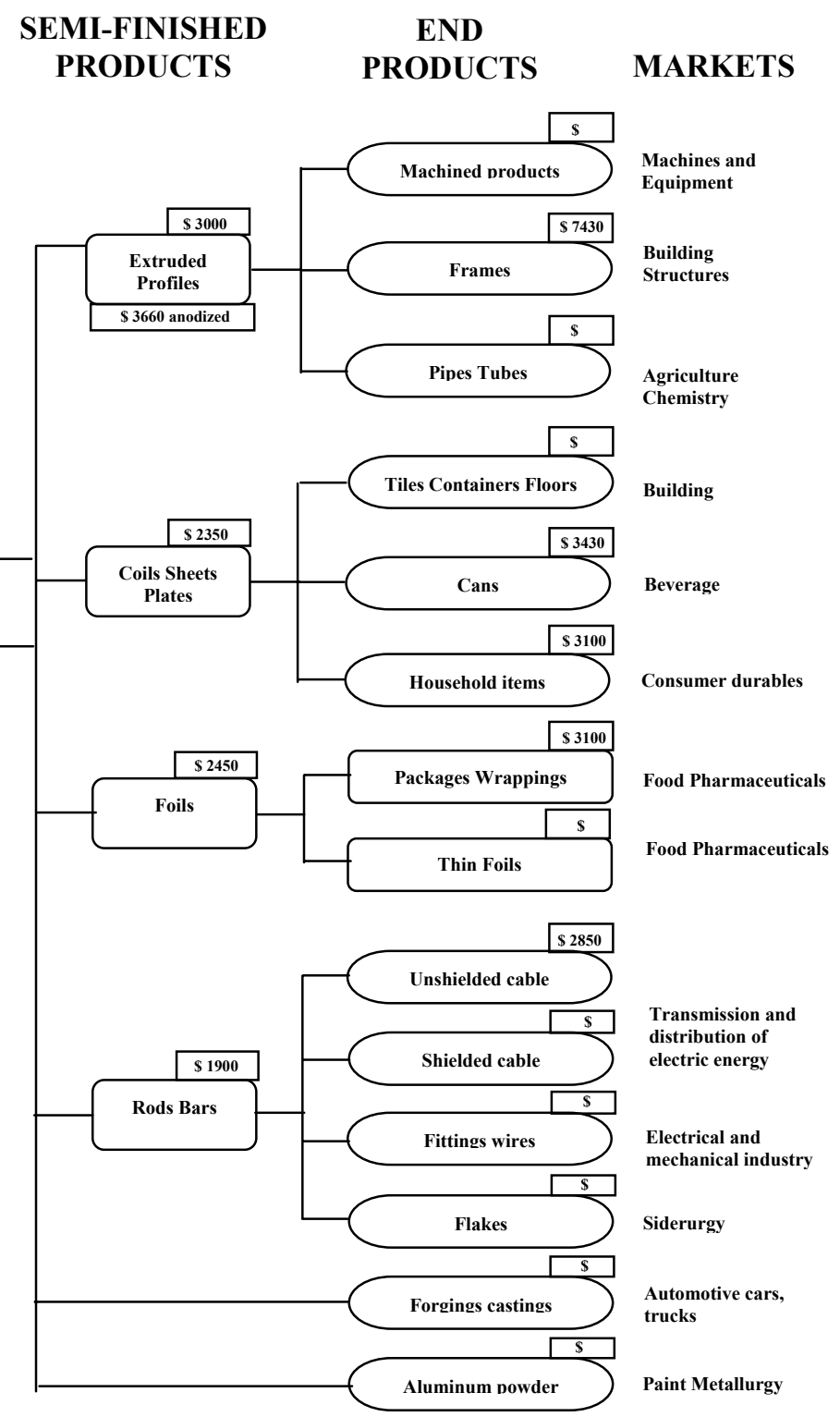


Figure 2. Aluminum Price

Ingot $99.7 \% \mathrm{Al}$

London Metal Exchange

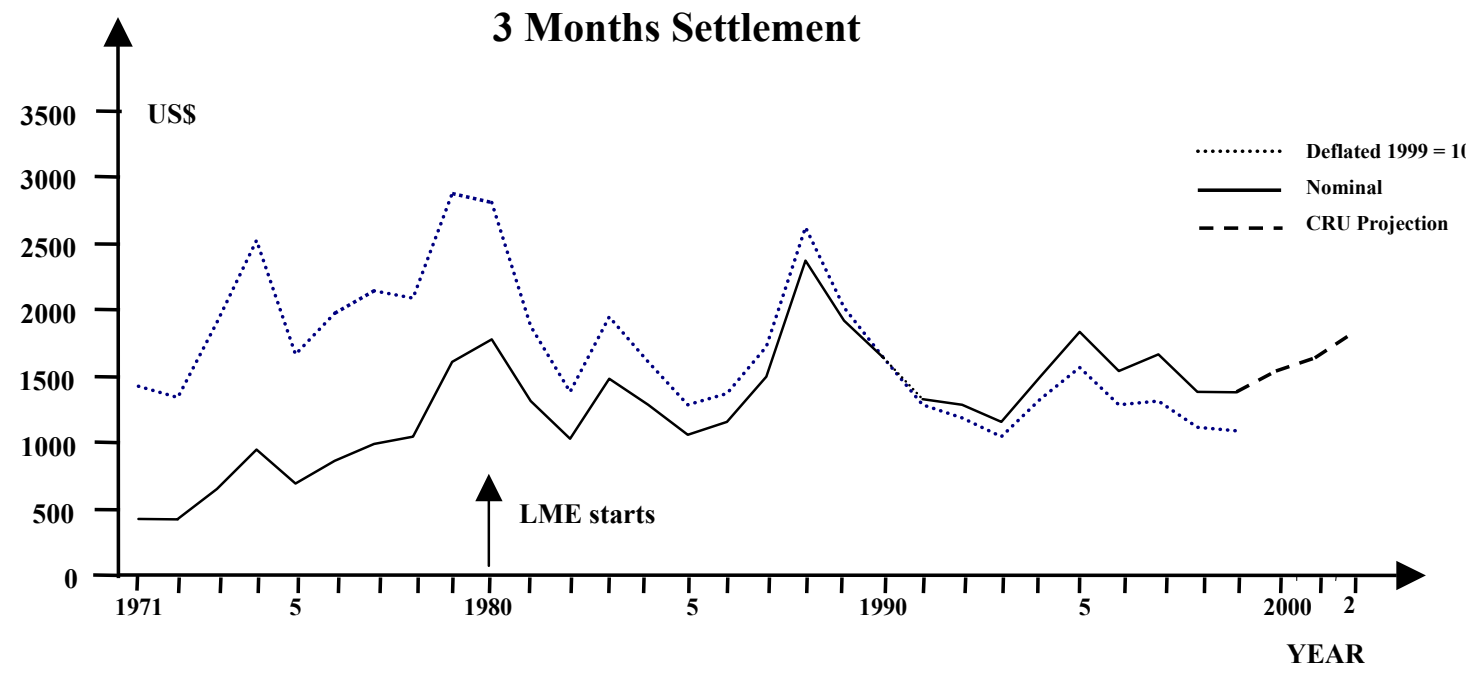

Source of Data: ABAL 
Figure 3: Brazil Aluminum Production and Consumption (1000 t)

1960-2000

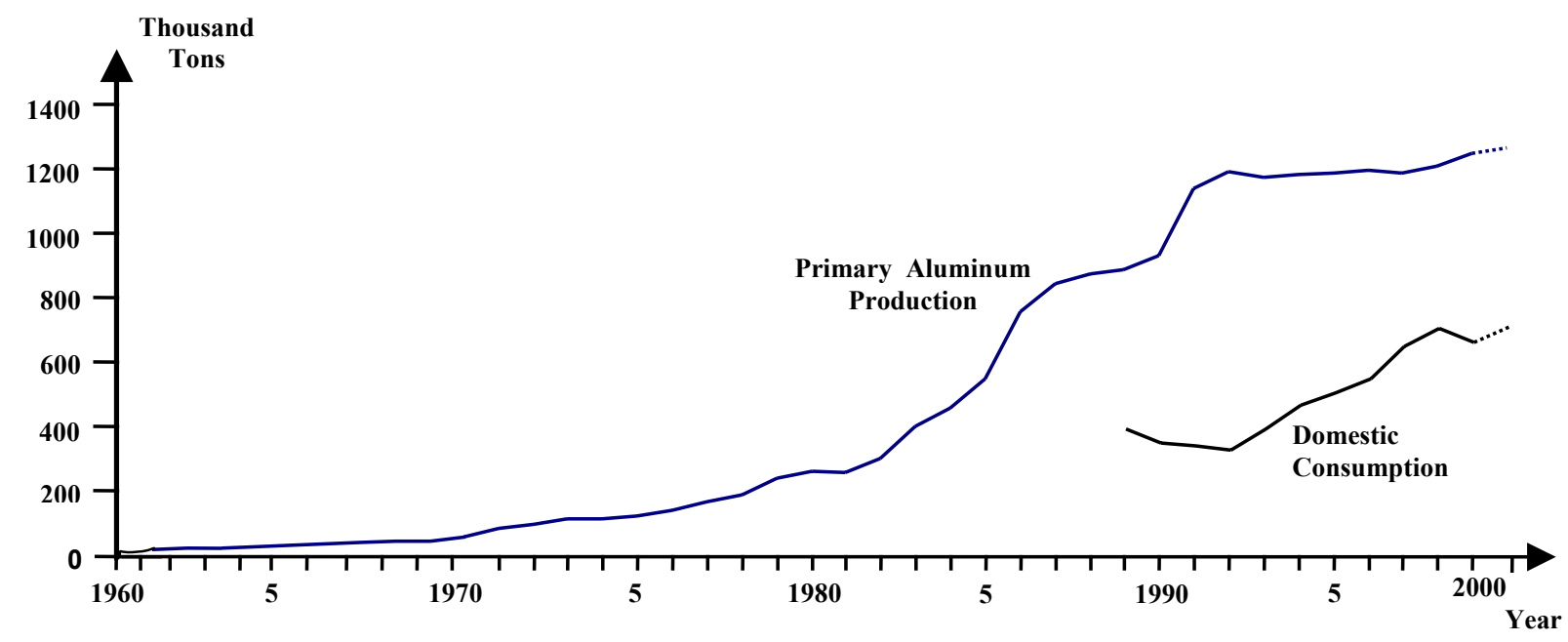

Source of Data: ABAL

Figure 4. Brazil Primary Aluminum Exports 1981-1999

(Ingots - Alloys)

FOB Thousand ISS

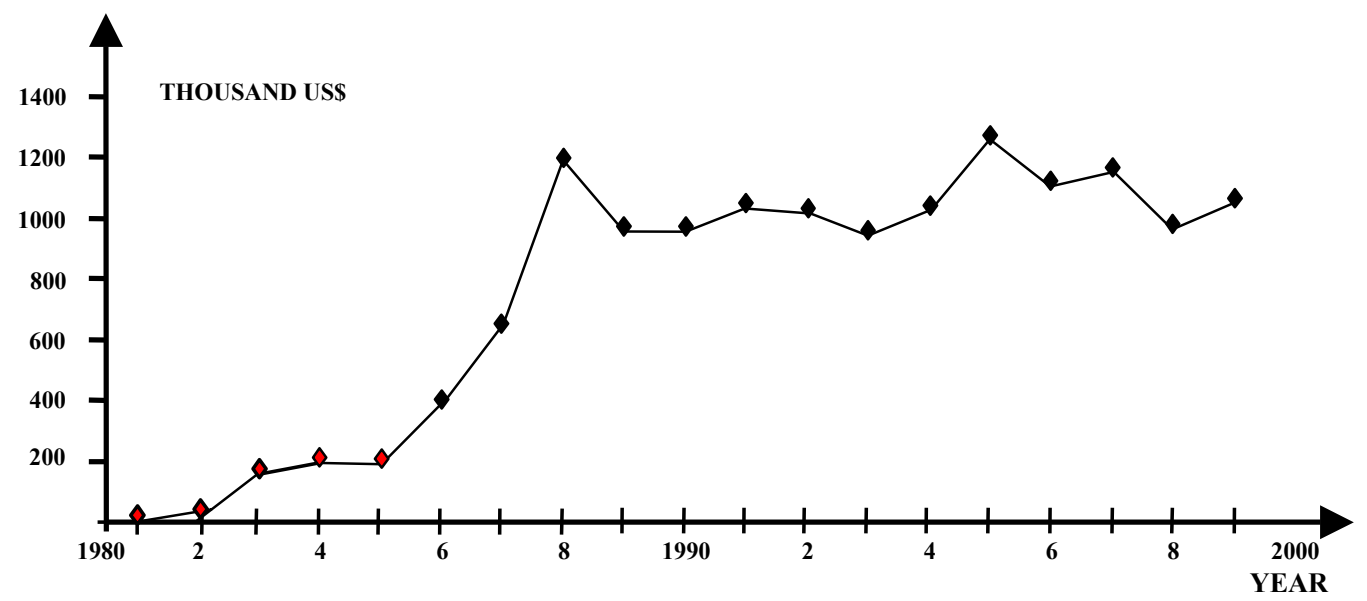

Source of Data: ABAL 